\title{
The Implementation of ADDIE Model in Developing Career Guidance Program in Senior High School
}

\author{
Indri Astuti \\ Universitas Tanjungpura, Pontianak, Indonesia \\ E-mail:indribk91@yahoo.com
}

\begin{abstract}
The research aims to reveal the factual design and conceptual design of the preparation of career guidance programs at Pontianak 3 State Senior High School. Sixty twelve grade science students and two guidance and counseling teachers were also the subjects of the survey. Quantitative data were obtained using questionnaires as main data and interviews as additional data. The results of data processing show that most of the assessment needs have been carried out in a high category. However, the response of the guidance and counseling (BK) teacher stated that there were still weaknesses in the factual model of the preparation of the BK program in the field of career guidance including the principal, homeroom teacher and subject teacher had not been involved in the preparation of the BK program. So this finding is the basis for the preparation of the conceptual design of career guidance programs, that the involvement of principals, homerooms and subject teachers has been apparent in the process of developing a career guidance program.
\end{abstract}

Keywords: ADDIE Model; Career Guidance Program; Factual Design; Conceptual Design

\section{INTRODUCTION}

The basis for consideration is the implementation of guidance and counseling programs in schools as an effort to facilitate students to be able to develop their potential in accordance with the tasks of their development. Students as individuals are developing toward maturity or independence need guidance to recognize and understand themselves and their environment in determining the direction of their lives in the future. In addition, there is a necessity that the individual development process does not always take place smoothly, or is sterile from problems. In other words, the development process does not always run in a linear, straight, or direction with the potential, expectations, and values adopted.

In accordance with the trend (tendency) of the guidance and counseling model that is developing today, the guidance and counseling developed are based on developmental tasks, namely those that are oriented towards facilitating students' potential, which includes personal, social, academic, and career aspects. For high school students, they will ultimately establish a career at the end of their studies. Careers are oriented towards advanced study, work and courses. Empirical data for 2018 new student admissions, Universitas Tanjungpura (UNTAN) capacity through national selection to enter state universities (SNMPTN) pathway 1,547 people (21.43\%) from applicants. 7216 people (78.57\%). This means that most do not pass to choose to work and improve the skills required for work. Or prepare to take the selection test the following year while high school is a secondary level of formal education equipping students to go on to college. But the limited number of tertiary institutions that are not in accordance with the number of high schools and graduates, the number of students accepted in PTN is limited, and students expect to obtain career information services that are appropriate to the needs of students. For this reason, career guidance programs are needed that are oriented towards student needs analysis, design, development, implementation, and evaluation (ADDIE).

Based on the above reality, concrete efforts are made to improve the quality of career guidance program preparation, one of which is through the ADDIE model, Benny (2014: 23). This study uses the ADDIE model to the design stage to reveal and describe the factual design and conceptual design of career guidance programs in Pontianak 3 State Senior High School. One of the competencies that must be possessed by a counselor is the ability to plan and manage counseling and guidance programs. The competency formulas are listed in the Indonesian Counselor Competency Standards, published by ABKIN (213) namely: 
Table I

Competencies and Indicators

\begin{tabular}{lrl}
\hline \multicolumn{1}{c}{ Competencies } & \multicolumn{2}{c}{ Indicators } \\
\hline $\begin{array}{l}\text { Designing a guidance } \\
\text { and counseling } \\
\text { program. }\end{array}$ & a. & $\begin{array}{l}\text { Applying } \\
\text { principles. }\end{array}$ \\
& b. $\begin{array}{l}\text { Conducting needs and } \\
\text { guidance counseling } \\
\text { services. }\end{array}$ \\
& c. $\begin{array}{l}\text { Formulate objectives and } \\
\text { prioritize guidance and } \\
\text { counseling programs. } \\
\text { Develop a program of } \\
\text { guidance and counseling. }\end{array}$ \\
& d.
\end{tabular}

2. Implementing a guidance and counseling program.

\begin{tabular}{l} 
h. $\begin{array}{l}\text { Applying the principles of } \\
\text { sustainability to the } \\
\text { guidance and counseling } \\
\text { program. }\end{array}$ \\
\hline
\end{tabular}

Needs analysis based on assessment results. Guidance and counseling teachers (BK) need to identify and formulate the needs of the tasks and the level of development of students, before formulating the objectives and design of development guidance and counseling programs. There are two things that need to be considered in identifying and formulating needs, namely; (1) assessing students' real needs or problems in the field; and (2) ideal school and community expectations of students. Student needs or problems can be identified through (1) student characteristics, such as physical aspects (health and function), intelligence, learning motives, attitudes and learning habits, temperament (cheerful, quiet, moody, or easily offended), and his character (such as honesty, discipline, and responsibility); or (2) development tasks, as a basis for providing guidance services.

One way to understand the needs of students as stated above is through measuring developmental tasks. To find out the developmental tasks of students can be done by using a variety of data collection instruments, one of which is the Inventory of Developmental Tasks (ITP). This ITP was developed by Sunaryo Kartadinata et al. Through research at all levels of education, including junior high school, the validity and reliability levels have been tested. Computerized software was developed to process ITP results, namely Developmental Task Analysis (ATP). This software is felt to be very helpful in efforts to improve the efficiency and management of guidance and counseling services in schools because information about students can be known quickly and accurately. Another assessment application is the AKPD (needs analysis of students) for grades 10,11 and 12 for each class with 50 different items tailored to the needs of students. The AKPD application consists of a set of instruments in the form of inventory of students' needs for classes 10,11 and 12 and application of data analysis for different classes. For this reason, according to Sunaryo (2013: 5), that facilitating student services is carried out comprehensively constructed through program components as an intervention strategy and delivery system. This dimension builds a comprehensive framework of guidance and counseling thinking that starts with the analysis of student needs.

The concept of career guidance for students: (1) Education and work in the context of guidance and counseling. High school graduates will be faced with the choice of going on to college or working even other alternatives to follow the skills needed in further study or work. Decision making for high school students is not an easy work to solve. Because high school education is a general formal high school, prioritizing the preparation of students to increase knowledge to continue the higher level and develop themselves in line with the development of 
science and technology. In line with Indri's research findings (2016: 58), the high qualification of students which is one of the demands for attending tertiary education indicates the awareness of students about the tight competition in higher education, especially PTN in the future. The orientation of student values toward higher education plays an important role in preparation and decision making. According to Herr and Cramer in Astuti (2016: 18) grouping the reasons for entering tertiary education into three categories, for (a) selfsatisfaction: continuing to college especially looking for self-identity and self-fulfillment. (b) pursuing a career: going on to college with the excuse of preparing to reach the goal of getting an award from a job. (c) avoiding: going to college is a decision to avoid something unwanted.

Here is Clark in Herr and Creamer (1994: 293), seeing that there are four dominant cultures in entering college, namely: collegiate, vocational, academic and nonconformist. (a) Collegial. The orientation adopted is to study in college to pursue social activities, so that academic interests are reduced. (b) Vocational. The orientation of learning in college to prepare themselves to meet the requirements in work. So that social and intellectual interests are less noticed. (c) Academic. The value orientation adopted is studying in college as a place to pursue science. So that social skills and work skills are considered and prioritize the development and mastery of science. (d) Nonconformists. This value orientation is that studying in a college is a place to look for self-identity that has freedom of expression.

With regard to the meaning of work, here is Herr and Creamer in Indri (2016: 25-26), that work is a person's needs and goals both economically, socially and psychologically. Work for someone is colored by one's personality. For that according to the trait approach and factors that individuals as organizations traits can be paired with types of work and training. Information about him and his work environment is a skill needed to make decisions. The following work environment and personal orientation include (a) Realistic environment. The characteristics of this environment stimulate people to move according to realistic forces by optimizing their potential. (b) Investigative environment. Its characteristics give priority to thinking intellectually rather than acting and encouraging the issue of intellectual problems. This type of person tends to work alone rather than with others. (c) Artistic environment. The characteristics of this environment require and appreciate free, ambitious and unsystematic activities. Prioritizing personal expression, emotion rather than logic. So that appreciate irregularity, imagination, and intuitiveness. (d) Social Environment. Its characteristics stimulate others, are cooperative, social and social activities are stronger. (e) Enterprising environment. Its characteristics show verbal abilities and skills to influence and control others to achieve organizational goals so that it tends to be ambitious, impulsive, uplifting and confident. (f) Conventional environment. Its characteristics demand all official, formal and self-control. Capabilities needed in an organized office environment. Biographical factors in the selection of higher education and employment were colored, including student gender, study program, school location, birth position, parental work, and academic achievement.

Development of career guidance and counseling programs designed based on analysis of user needs. In the opinion of Dewi (2018: 21) that the ADDIE approach is very flexible, not binding, it can be started from anywhere according to needs. Among them are student characteristics, dominant problems that arise as well as career guidance curriculum. The data collection tool used is a tool to reveal problems or inventory development tasks. For the development of the program, the initial design of the career guidance program standardization process was developed through theoretical validation, namely material experts, design and empirical validation, namely high school students. The core task in letter A of ADDIE is to trace the causes and formulate solutions to problem-solving performance (Dewi and Uwes, 2018: 26). For that the teacher's guidance and counseling performance in compiling the program is based on: (a) students' real needs, (b) guidance activities are arranged based on the priority scale, (c) the program is arranged in an ideal but realistic in its implementation. So that the operational program can be implemented in the education unit including high school, for this reason, the program should pay attention to the principles of balance and continuity as follows: (a) Classical services: through information services, orientation, learning, placement of distribution (b) Group services: includes group guidance, group counseling. (c) Individual services: covering individual counseling, mediation services, and consultation. Furthermore, the formation of career guidance programs can be distinguished into two, namely developing existing programs and developing new programs that do not yet exist. According to Benny (2014: 55). The stages of the preparation of both programs are the same, covering the stages of needs analysis, planning, development, implementation, and evaluation (ADDIE). The five stages synergize so that they produce career guidance programs according to the characteristics of students. The ADDIE procedure is a dimension of the procedure for developing a conceptual model (Rusdi: 2018: 90). The conceptual model is a verbal description of a particular reality, representing a system of concepts to help actualize the performance system in compiling the program.

\section{RESEARCH METHOD}

Survey research has the objectives, namely: (1) describing the natural state at the time, (2) identifying conditions in a measurable manner, and (3) determining something specific relationship. This research was conducted by conducting a direct visit or survey to the Pontianak 3 State High School, collecting data relating to career guidance and counseling programs, then analyzing and interpreting them to answer research problems and draw conclusions. This research uses the ADDIE model stages (analysis, design, development, implementation, and evaluation). The stages carried out in this study are the stage of needs analysis and model design. The analysis phase 
carried out is (1) analysis of career competencies that must be mastered by students, (2) analysis of career material needed by students. The next stage of the design is based on the results of the needs analysis, the design of a factual career guidance program and the design of a conceptual career guidance program are prepared. The draft is arranged to cover the activities of the principal, guidance and counseling teacher, homeroom teacher and subject teacher. So that there are integrated and synergistic activities among school personnel in compiling and implementing career guidance programs in schools. The place of research at Pontianak 3 State Senior High School is considered a state school with geographical conditions in the middle of the city. The characteristics of the subjects of this study were two teachers who were certified and counseled. Active students are the target of career guidance programs in class XII of Science as many as 60 people. Data collection techniques are interviews, questionnaires. Questionnaire data were analyzed by percentage, interview with descriptive narrative.

\section{RESULT AND DISCUSSION}

Description of the factual design analysis of career guidance programs at Pontianak 3 State Senior High School, the preparation of career guidance programs by guidance and counseling teachers has not involved the principal. The role of the principal is only to monitor the performance of the teacher's role in the education process. Specifically, the principal has not monitored the performance of the guidance, and counseling teacher in the preparation of career guidance programs, as well as the involvement of homeroom teachers and subject teachers, have not been conducted.

Design of Career Factual Programs

Based on the factual design above, the Conceptual Design of Career Guidance Program in Pontianak 3 State Senior High School was formulated. Preparation of career guidance programs by guidance and counseling teachers has involved the principal. The role of the principal is not only monitoring the performance of the teacher's role in the education process. The involvement of the homeroom teacher and subject teacher has been done.

\section{Design of Conceptual Programs For Career Mentoring}

Based on descriptive analysis quantitatively, it can be used as a basis for formulating the strengths and weaknesses of the factual model of guidance and counseling program in the field of career guidance. The results showed 95\% stated that assessment needs had been carried out in a high category. This means that the preparation of career guidance includes (1) the needs assessment activities have been carried out by all guidance and counseling teachers, but the types of instruments used are still very limited. (2) data processing activities, some have used computer aids even though they are very minimal with simple software.

But the teacher's guidance and counseling response state there is still weakness in analyzing student data. It means that the weaknesses of the factual model for the preparation of career guidance programs are: (1) the role of the principal is only to monitor teacher performance in the education process, not specifically monitor the teacher's guidance and counseling performance in the preparation of career guidance programs; (2) needs assessment activities, including (a) the instrument is not carried out data and only stored in documents, because the workload is a lot, time is limited. Then the instruments used have not been tested for validity and reliability. While doing quality assessment needs must be based on scientific evidence (evidence-based assessment). Need assessment will prove more consistent, meaningful, and useful than assessment without going through validation tests. Therefore a teacher of guidance and counseling before carrying out data analysis needs to examine the instrument to be used. The instrument validation test should be done through expert validation by involving universities or using statistical analysis. (b) special instruments for career guidance are not yet available; the instruments used are universal for all fields of guidance so that instruments that can be used still have weaknesses. (c) needs assessment is still done manually, so the database has not been created. Database benefits can be updated at any time, so information fulfillment and freshness can always be available; (d) needs assessment activities to require a long time, teacher guidance and counseling performance become less efficient. (3) data processing activities, many are still done manually, so the information obtained is very limited, and the information is less "fresh." (4) guidance and counseling teachers acknowledge lack of understanding and experience in conducting need assessment.

Constraints experienced by guidance and counseling teachers at the time of need assessment: (a) limited time, many task loads and limited time available; (b) the value of subject teachers is not complete, so the data for assessment needs is incomplete; (c) guidance and counseling teachers are inexperienced when they have to carry out need assessment activities. Guidance and counseling teachers also admitted difficulties in conducting data analysis, because they did not understand how to analyze open questionnaires, did not yet master the method of processing data, and the limitations of instruments. Even guidance and counseling teachers understand the activities of need assessment only as a form of data collection. Constraints experienced by guidance and counseling teachers are related to (a) interpretation of data: limited knowledge and experience, and difficulties in interpreting data. Even guidance and counseling teachers understand the data interpretation activities only as describing data and interpreting data (b) Priority Scale Determination Activities: guidance and counseling teachers have difficulty when determining student needs so that when determining the priority scale there is a mismatch with student needs. Meanwhile, the priority scale will be used to formulate goals in providing guidance services. Starting from the incompatibility of data used can have an impact on the stages of further programming. (c) Formulation Activities Objective: guidance and counseling teachers lack understanding in formulating guidance goals, they say that goal formulation is based on UCA (Understanding, Comfort, and Action), whereas UCA is an indicator for evaluating counseling and 
development tasks, as well as understanding the material by students. (d) Program Procedure Activities: that the difficulties experienced by the guidance and counseling teacher in preparing the program lie in the need assessment activities, lack of skills in compiling the program, time constraints. Guidance and counseling teachers assume that the preparation of the program requires a long time, especially in the need assessment activities, and data interpretation. The aforementioned difficulties have caused the guidance and counseling teachers in compiling the program only to replace the year of manufacture. These conditions form the assumption that the guidance and counseling program does not need to be compiled every year. Related to the obstacles experienced by guidance and counseling teachers, it requires the help of a management information system.

But the advantages of the guidance and counseling program in the field of career in Pontianak 3 State Senior High School include (1) the assessment of student needs conducted by the teacher of guidance and counseling, but the types of instruments used are still very limited. (2) Data processing activities already exist that are processed using computers, but software is still simple.

\section{CONCLUSION}

Based on the explanation above, it can be concluded that: (1) the factual model of the preparation of career guidance programs at Pontianak 3 State Senior High School, that the principal, homeroom teacher, subject teacher has not been involved in the preparation of the program. The role of the school principal monitors the performance of teacher guidance and counseling priorities in the learning process, does not specifically monitor the performance of teacher guidance and counseling in the preparation of career field programs. Student needs assessment activities have been carried out, but data is not processed and stored in document form because the workload is large, time is limited. Special instruments for career guidance are not yet available; the instruments used are still common to all fields of guidance. Need assessment is still manual, so it takes a long time, teacher guidance and counseling performance becomes less efficient; (2) Preparation of conceptual design of career guidance programs assisted by management information systems can involve the principal to monitor the performance of guidance and counseling teachers in preparing programs, subject teachers and homeroom teachers to identify problems with learning difficulties in the classroom. Guidance and counseling teachers develop career guidance programs ranging from the need assessment to program procedures and produce career guidance programs. Career guidance instrumentation uses the application of management information systems so that the suitability of the program is obtained with the needs of students.

Although many programs provide guidance and counseling teacher benefits in carrying out career services to students but still need guidance and counseling teacher guidance in (1) the design of career guidance programs assisted by management information systems (SIM) can be used to improve their competence in developing guidance programs and counseling and information technology. (2) The provisions of PP number 74 of 2008 that guidance and counseling teachers have a minimum workload of 150 to 250 students, then the SIM for guidance and counseling is a solution to these provisions, so as to reduce the complexity of the teacher's guidance and counseling work. (3) Collaborating with provincial and district education offices to facilitate: (a) the implementation of mentoring and counseling teacher training in using MIS in guidance and counseling so that it can improve the performance of mentor teachers and human resource development as material for consideration of teacher guidance and counseling. (b) preparation of career guidance programs assisted by management information systems supporting the education ministry's policy on internet procurement for each school, so that it is expected to improve the efficiency of the teacher's guidance and counseling work at the school. (c) Preparation of a SIM assisted career guidance program is expected to be utilized by the education office as a training eye for developing competency in information technology for guidance and counseling teachers in Pontianak city and in West Kalimantan province. (4) Guidance and Counseling Professionals Association As consideration in improving the professionalism of guidance and counseling teachers in using information technology in pedagogical and professional competencies. (5) The field of school curriculum through the development of a guidance and counseling study program curriculum. The curriculum review activities include including one of the materials on information technology in guidance and counseling with the hope that the guidance and counseling study program graduate graduates have the ability to use information technology while on duty at school. The use of management information systems can be integrated into the science of guidance and counseling, through the course of guidance and counseling management and information technology and innovation guidance and counseling. So students graduating from Guidance and Counseling Study Program of Faculty of Teacher Training and Education in UNTAN are ready to use IT especially management information systems when PPL or work as guidance and counseling teachers in schools and outside school settings.

\section{REFERENCES}

Astuti, Indri. (2015). Model pembelajaran konseling kelompok dengan pendekatan konstruktivisme. Teknologi Pendidikan Program Pasca sarjana Universitas Negeri Jakarta berkerjasam dengan Ikatan Profesi Teknologi Pendidikan Indonesia (IPTPI). Vol 18.No.1. (1-9)

(2016). Pandangan siswa SMA terhadap Perguruan Tinggi. Penelitian Mandiri. FKIP UNTAN. Pontianak.

Gustafson, Kent L. and Branch, Robert Maribe. (2002). Survey of Instructional Development. New York: Eric Syracause University. 
Herr and Cremer (1984). Carier Guidance and Counseling Through The Life Span: Systematic Approaches' Boston Little Brown Co.

Lesslie Briggs. (1998). Instructional Design. Ed. New Jersey: Techn. Publis.

M. Rusdi. (2018). Penelitian Desain dan Pengembangan Kependidikan. Rajawali Pers. Jakarta: PT Raja Grafindo Persada.

Kartadinata, S. (2013). Konselor Bermartabat dan Konselor Otentik. Kolegial Prodi BK. 10 September 2013. Bandung: Universitas Pendidikan Indonesia.
Prawiradilaga. D.S and Uwes Anis Chaeruman. (2018). Teknologi Kinerja. Prenada Media Group. Jakarta: Prenada Media Group.

Pribadi, Benny. (2014). Desain dan Pengembangan Program Pelatihan Berbasis Kompetensi. Jakarta: Prenada Media Group. - (2018). Konsep Esensial Teknologi Pendidikan. Jakarta: APS-TPI Dian rakyat. . (2017). Media dan Teknologi dalam Pembelajaran. Jakarta: Prenada Media Group.

Sugiyono. (2015). Metodologi Penelitian Pendidikan. Bandung: Alfabeta. 